UDC: 616.89-008.19-036.1-07:378.091.12.011.3

DOI: https://doi.org/10.24195/2414-4665-2017-3-12

\begin{abstract}
Mariana Dikal,
PhD (Candidate of Medical Sciences), associate professor, Department of Bioorganic and Biological Chemistry and Clinical Biochemistry,
\end{abstract}

Oksana Cherniukh,

PhD (Candidate of Medical Sciences), associate professor, Department of Bioorganic and Biological Chemistry and Clinical Biochemistry,

Tetiana Bilous,

PhD (Candidate of Medical Sciences), associate professor,

Department of Pediatrics and Children Infectious Diseases,

Nina Voitkevych,

senior lecturer, Department of Foreign Languages,

Higher State Educational Establishment of Ukraine "Bukovinian State Medical University",

2, Teatralna Square, Chernivtsi, Ukraine

\title{
PECULIARITIES OF FORMATION AND SIGNS OF EMOTIONAL BURNOUT SYNDROME IN MEDICAL UNIVERSITY TEACHERS
}

Peculiarities of the development and signs of emotional burnout syndrome among teaching staff of theoretical departments at Higher State Educational Establishment of Ukraine "Bukovinian State Medical University" have been examined. In order to assess the degree of emotional burnout the adapted $V$. Boyko's method was applied, according to which not only the signs of emotional burnout, its degree of the formation and stages of the development can be detected, but also the availability of psychosomatic and psycho-vegetative disorders. The formation of emotional burnout syndrome among university teachers is considered to have the following three stages: exertion, resistance and exhaustion. The exertion stage is predominantly characterized by excessive worries caused by psychological traumatic experience, anxiety and depression. The resistance stage is manifested in emotional thriftiness and emotional-moral disorientation. The exhaustion stage is characterized by emotional deficiency, psychosomatic and psycho-vegetative disorders. It has been revealed that the two stages of emotional burnout - exertion and resistance - were developed in 2 teachers out of the 27 participants of the sample. Their main symptoms are felling of being cornered which is the indicative of the development of intellectual-emotional block condition, desire to finish working day as soon as possible, feelings of anxiety and depression with simultaneous formation of professional duty reduction symptom. The resistance stage has been found in six teachers. It manifests in reduction of professional duties, low interest in work and deterioration of professional activities. The resistance and exhaustion stages have been found in four teachers. Their most pronounced symptoms are greater emotional thriftiness, which manifests in the limited communication with the audience, decreased interest in work and emotional deficiency, when people lose their professional abilities, change positive emotions into negative ones, become rude in communication. All the three stages of emotional burnout syndrome have been detected in four teachers (mostly women). Their dominating signs are worries concerning psychological traumatic circumstances characterized by intensified irritation and lack of confidence to people, accumulated dissatisfaction of the situation. At the same time, its most pronounced sign is wide emotional thriftiness which manifests in the lack of desire to communicate with the audience and decreased interest in work. It has been revealed that the signs of emotional burnout syndrome of university teachers do not depend on the field of study taught by them, although the emotional burnout syndrome develops mainly in the teachers who teach their subject in English.

Keywords: emotional burnout syndrome, lecturer, exertion stage, resistance stage, exhaustion stage, emotional thriftiness.

\section{Introduction}

Emotional burnout syndrome is a rather common phenomenon today. This condition is manifested by emotional, mental and physical exhaustion resulting in paralysis of our strength, feelings and is accompanied by lack of joy and satisfaction of life in response to a long influence of stressful and psychological traumatic factors (Flook et al., 2013). From year to year the cases of burnout syndrome have become more frequent because the tension of modern life accelerates quickly increasing the level of exertion on the personality, and in its turn it results in exhaustion and deterioration of professional activity.
The first works on this issue appeared in the USA. In 1974, the American psychologist Herbert Freudenberger described this phenomenon and called it "burn-out" to characterize a psychological condition of healthy people who are in intensive and close communication with patients (customers) under emotionally loaded atmosphere while giving professional aid (Jepson et al., 2006).

Most frequently (from 30 to $90 \%$ ) emotional burnout syndrome occurs among doctors, teachers, psychologists, social workers, rescuers and law-enforcement workers (Lisniak at al., 2014). There are the following three main groups of factors playing an important role in the formation of bur- 
nout syndrome: personal one is characterized by person's dissatisfaction of his/her professional advancement, lack of motivation in work, low salary; role which is manifested in the lack of accurate or irregular distributed responsibilities for one's professional duties and integration for successful final result of work; organizational which is characterized by intensive communication, conflicts with colleagues and the lack of the authorities' support (Koloskova et al., 2012). One of the main causes of the development of this syndrome is psychological and mental overstrain leading to disorders of equilibrium as a result of a long occupational stress (Abbas et al., 2013).

Researchers distinguish the following five groups of symptoms peculiar for emotional burnout syndrome:

1. Physical symptoms: physical fatigue, exhaustion, weight changes, insomnia, poor general condition of health, irregular respiration, nausea, dizziness, high blood pressure, ulcers and inflammatory skin diseases.

2. Emotional symptoms include lack of emotions, pessimism, cynicism, hard-heartedness in work and personal life, indifference and feeling of helplessness or hopelessness, aggressiveness, irritability, anxiety, intensification of irrational worries, inability to concentrate, depression, feeling of fault, hysteria, isolation.

3. Behavioral symptoms appear during professional activity and manifest themselves in tiredness, apathy to meals, lack of physical activity, smoking, consumption of alcohol, drugs, impulsive emotional behavior.

4. Intellectual symptoms involve low interest in new theories and ideas in work, alternative approaches to solve problems, boredom, anguish, apathy, loss of interest in life, indifference to self-improvement and innovations, passive participation or rejection from participation in experiments and formal performance of work.

5. Social symptoms include low social activity, low interest in leisure time, hobbies, limited social contacts, feeling of isolation, lack of understanding of other people, feeling lack of support of family, friends, and colleagues.

Therefore, burnout syndrome is characterized by the combination of disorders in psychic, somatic and social spheres of life (Schaufeli et al., 2009).

The literature review shows that there are several theories that single out the stages of burnout syndrome development. One of the most prevailing theories is $\mathrm{J}$. Greenberg's five-stage model (Holloway et al., 2000):

$1^{\text {st }}$ stage ("honey moon") - a worker is satisfied and enthusiastic with his/her work and tasks. Although, with time due to job stresses the worker becomes less active and his/her professional activity starts bringing less satisfaction.

$2^{\text {nd }}$ stage ("lack of fuel") - fatigue, apathy and problems with sleep appear. Under conditions of lack of additional motivation and stimulation a worker loses interest in work and productivity of his/her activity decreases.

$3^{\text {rd }}$ stage (chronic symptoms) - excessive work without rest, especially in workaholics, results in exhaustion and susceptibility to diseases as well as psychological worries - chronic fatigue, subtle senses of anger or depression, feeling of being cornered. $4^{\text {th }}$ stage (crisis) - chronic diseases develop, and as a result the ability to work is partially or completely lost.

$5^{\text {th }}$ stage ("breaking through the wall") - physical and psychological problems transfer into an acute form and may provoke the development of dangerous diseases threatening life. Due to these problems the person's career is at risk.

Some Ukrainian scientists (Zaichykova, 2005) differentiate the following three phases of burnout syndrome formation:

- exertion phase is characterized by worries of psychological-traumatic situations, self-dissatisfaction, feeling of being cornered, anxiety and depression;

- resistance phase includes the following signs: inadequate selective emotional reactions, emotional-moral disorientation, wide sphere of emotional thriftiness; reduction of professional duties;

- exhaustion phase is characterized by emotional deficiency, emotional and personality remoteness, psychosomatic and psycho-vegetative disorders.

Considering the above mentioned issues, the study of the mechanisms of emotional burnout syndrome formation and peculiarities of its manifestation in university teachers is topical and perspective for further search of methods of its diagnostics and prevention among high school teachers (Patiraj et al., 2009).

The paper aims to study the peculiarities of the development and manifestation of burnout syndrome in teachers of medical university's theoretical departments who teach their subjects in Ukrainian and English, as well as their comparative analysis.

\section{Research methods}

The study involved 27 teachers of the Departments of Bioorganic and Biological Chemistry and Clinical Biochemistry, Medical Chemistry, Normal Physiology and Pharmacology of Higher State Educational Establishment of Ukraine "Bukovinian State Medical University" (Chernivtsi). The average age of the respondents was $38,40 \pm 1,95$, men constituted $18 \%$ of the sample, women $-82 \%$, their average working experience was $17,40 \pm 2,13.85,2 \%$ of the workers were married, and 7,4\% of them were single. $92 \%$ of them have children. The respondents' working day lasts on the average for $8,00 \pm 0,26$ hours. In order to examine the degree of the respondents' emotional burnout the adapted V. Boyko's method (Boiko, 2004) was applied according to which not only the signs of emotional burnout syndrome, degree its formation and stages its development can be detected, but also the availability of psychosomatic and psycho-vegetative disorders as well. The respondents were asked to fill in the questionnaire containing 84 statements. The results were interpreted according to three phases including four symptoms each. The total score was calculated for each out of 12 signs as well as the total score for every out of 3 stages of emotional burnout formation. In case of the total sum of scores was less than 9, the symptoms of emotional burnout syndrome were considered to be unformed; with the total sum of 10-15 the symptoms were considered to be at the stage of their formation; and in case of 16 and more scores, the symptoms were considered to be formed. The 
total sum for the stage/phase of emotional burnout less than 36 was not indicative of a formed one, in case of 37-60 - it was considered to be in the process of its formation, and with the total sum more than 60 it was considered to be formed. The results obtained were analyzed by means of Statistica 7.0 StatSoft Inc. with the use parametric and non-parametric methods of calculation.

\section{Results}

The examination of 27 teachers working at the Departments of Bioorganic and Biological Chemistry and Clinical Biochemistry (10 persons - 37\%), Medical Chemistry (4 persons - 15\%), Normal Physiology (7 persons - 26\%) and Pharmacology (6 persons - 22\%) has not revealed any peculiarities of emotional burnout syndrome depending on the subject they teach.

Although emotional burnout symptoms were developed mainly in the respondents who teach their subjects in English (44\%). The following symptoms have been found: inadequate selective emotional reaction and emotional-moral disorientation manifested in uncontrolled impact of their mood on the relations with the surrounding people, development of indifference in communication with students and teachers. In addition, the formed emotional thriftiness symptom is characterized by unsociability, detachment, unwillingness to interact with people, as well as the symptom of educational duties reduction manifested in the desire to spend less time on performing professional duties.

The phases of exertion and resistance have been revealed in 2 teachers $(7.5 \%)$ from the sample. The main symptoms of the exertion phase are feeling of being cornered which is indicative of the development of intellectual-emotional block condition and the desire to finish working day as soon as possible. At the same time anxiety and depression signs are developed as well. The resistance phase is manifested in the development of professional duties reduction symptom.

The resistance phase was found to be formed in six teachers with dominating signs of professional duties reduction, low interest in work and deterioration of professional activity.

The resistance and exhaustion phases were developed in four $(15 \%)$ teachers. The most prominent symptoms were increase of emotional thriftiness, which manifested in limited communication with the audience and reduced interest in work, emotional deficiency when people lose their professional abilities changing positive emotions into negative ones, and become rude in communication.

All the three phases of emotional burnout syndrome were developed in $15 \%$ of the teachers (mostly women). They had the following symptoms: worries concerning psycho-traumatic circumstances characterized by intensified irritation and distrust to people, situational dissatisfaction. At the same time, the symptom of emotional thriftiness increase was the most pronounced which manifests in disinclination to communicate with the audience and reduced interest in work.

Nevertheless, our investigation demonstrates that ten teachers $(37 \%)$ have not any developed phases of emotional burnout. It indicates the high level of their professionalism and stable psycho-emotional state able to prevent the negative impact of stressful situations at work while performing professional duties.

\section{Discussion}

Against the ground of two clearly formed symptoms of inadequately selective emotional reaction and reduction of professional duties (see fig. 1) further formation of a number of syndromes occurs: worries concerning psycho-traumatic circumstances, anxiety and depression, emotional and moral disorientation, increase of emotional thriftiness and emotional deficiency, etc. The rate of their maturity reaches 12,714,7 , that is $80-90 \%$. It is these syndromes that are able to intensify emotional instability and imbalance in the psychoemotional system of the personality eliminating the possibility of self-restoration and self-protection. This chain reaction results in destructive processes of psycho-emotional sphere and disorders of perception and an adequate reaction to social surroundings. The interrelations and communication with students and colleagues are destabilized; there is a lack of positive emotions in interaction with family members and friends. In case of the lack of effective protective mechanisms, it can result in irreversible negative consequences and conflict situations for both the people affected by this syndrome and those who interact with them. To overcome an initial moment of sensitization and formation of certain tolerance and "protective reaction" in response to the formation of phases of emotional burnout certain conditions should be created to form emotional immunity (Balakiryeva, 2015).

It should be noted that a third of the teachers (37\%) maintained their stable positive condition which is a guarantee of an internal potential to resist burnout syndrome within the group.

A necessary requirement for stabilization and stability of psycho-emotional sphere concerning negative signs of burnout is alternation of mental activity and its diversity (lectures, practical classes, consultations, training and conferences), work with students ("vertical direction") and with colleagues ("horizontal direction", changing mental and physical load to eliminate exertion and overcome emotional imbalance (Gagalan, 2012).

An interesting fact is that "personal dissatisfaction" and "feeling of being cornered" symptoms remained at a rather high level of their formation: the score was 6,7 and 6,8 respectively out of essential 16 . These results may indicate the crisis or a crucial point first of all for the teacher, not the personality, which shows the need for performing the factor analysis of the educational system environment and the state consolidation concerning this issue.

Therefore, the study of emotional burnout syndrome among the teachers of theoretical departments of Higher State Educational Establishment of Ukraine "Bukovinian State Medical University" has shown that the mostly formed symptoms of emotional burnout are inadequate selective emotional response accompanied by the uncontrolled impact of mood on the relations with colleagues and reduction of professional duties characterized by the decreased intensity 
of educational activity and the desire to spend as less time as possible to perform their professional duties. The symptoms of worries concerning psycho-traumatic circumstances, increase of emotional thriftiness sphere and emotional defi- ciency accompany the stage of their formation.

\section{Indices of emotional burnout rate among teachers}

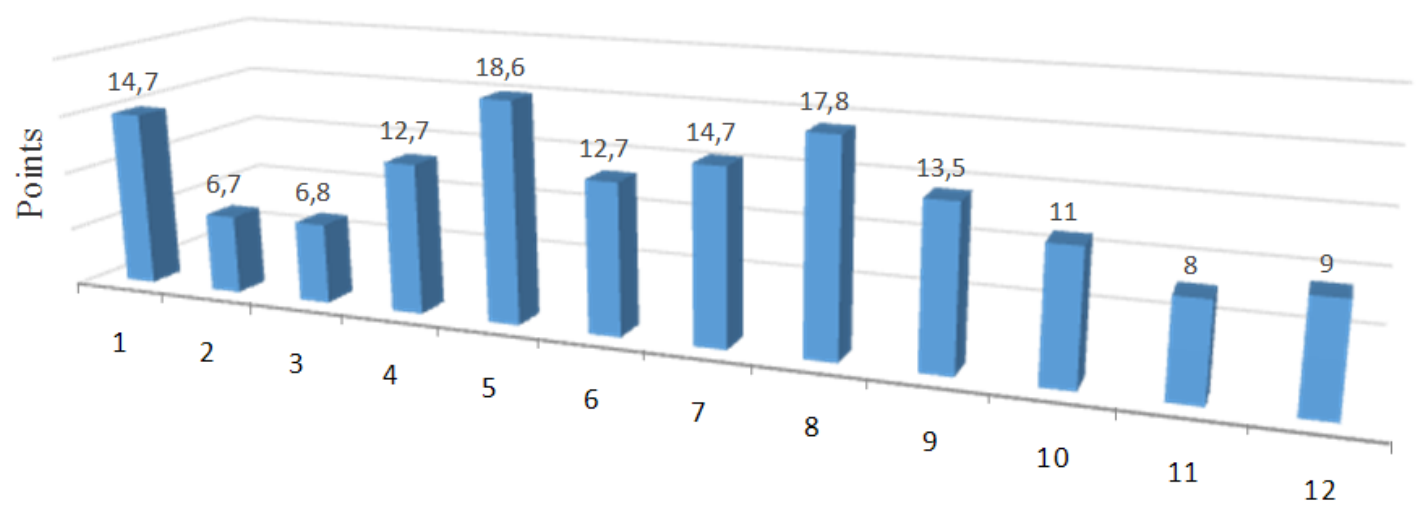

Symptoms of emotional burnout(1-12)

Fig. Indices of emotional burnout rate among teachers

Symptoms of burnout: 1) worries concerning psycho-traumatic circumstances, 2) personal dissatisfaction, 3) feeling of being cornered, 4) anxiety and depression, 5) inadequate selective emotional reaction, 6) emotional-moral disorientation, 7) increase of emotional thriftiness, 8) reduction of professional duties. 9) emotional deficiency, 10) emotional rejection, 11) personality rejection, 12) psychosomatic and psycho-vegetative disorders.

\section{Conclusions}

1. Emotional burnout syndrome in teachers is developed in the following three stages: the exertion one is characterized by excessive worries caused by psychological traumatic experience, anxiety and depression; the resistance stage is manifested in emotional thriftiness and emotional-moral disorientation, and the exhaustion stage is characterized by emotional deficiency, psychosomatic and psycho-vegetative disorders.

2. The signs of emotional burnout syndrome do not depend on the teachers' field study, although the emo-

\section{REFERENCES}

1. Abbas, S. G., \& Roger, A. (2013). The impact of work overload and coping mechanisms on different dimensions of stress among university teachers. GRH, 3 (8), 93-118. doi: 10.3917/grh.133.0093.

2. Balakiryeva, K. O. (2015). Profilaktyka ta podolannia profesiinoho ta emotsiinoho vyhorannia: metod. rekomend [Prevention and overcoming professional and emotional burnout: guidelines]. Retrieved from: http://www.slideshare.net/undpukraine/ss-48391940 [in Ukrainian].

3. Boiko, V. V. (2004). Energiya emotsiy [The energy of emotions]. $2^{\text {nd }}$ ed. rev. St. petersburg: Piter [in Russian].

4. Flook, L., Goldberg, S. B., Pinger, L., Bonus, K., \& Davidson, R. J. (2013). Mindfulness for Teachers: A Pilot Study to Assess Effects on Stress, Burnout, and Teaching Efficacy. Mind, Brain, and Education, 7 (3), tional burnout syndrome mainly develops in those lecturers who teach their subjects in English.

3. The following emotional burnout symptoms are found to be the most mature in the surveyed: inadequate selective emotional response accompanied by the uncontrolled impact of mood on the relations with colleagues and professional duties reduction manifested in the decreased intensity of educational activity and the desire to spend as less time as possible to perform their professional duties.

\section{2-195. doi: 10.1111/mbe.12026.}

5. Gagalan, Yu. (2012). Resursy dlia podolannia stresu. Stresy u profesiinii diialnosti vchytelia [Resources to combat stress. Stress in the professional work of the teacher]. Psykholoh-Psychologist, 4, 29-31 [in Ukrainian].

6. Holloway, F., Szmukler, J. \& Carson, J. (2000). Support systems. 1. Introduction. Advances in Psychiatric Treatment, 6, 226-235.

7. Jepson, E. \& Forrest, S. (2006). Individual contributory factors in teacher stress: The role of achievement striving and occupational commitment. British Journal of Educational Psychology, 76(1), 183-197.

8. Koloskova, O. K., Polishhuk, M. I. \& Vorotnyak, T. M. (2012). Osoblyvosti rozvytku ta proiaviv syndromu emotsiinoho vyhorannia $\mathrm{v}$ likariv-pediatriv [Features of development and manifestations of the syndrome of emotional burnout in pediatricians]. Zdorovie rebenka - 
Clinical pediatrics, 7(42), 19-22.

9. Lisniak, M. A., Gorbach, N. A., Loginova, I. O. \& Mashukova, M. A. (2014). Emotsionalnoe vygoranie prepodavatelei meditsinskogo vuza: problema i puti ee resheniya [Emotional burnout medical school teachers: the problem and its solutions]. Sibirskoie emotsionalnoe obozreniie - Siberian Medical Review, 6, 101-105. Retrieved from: http://cyberleninka.ru/article/n/emotsionalnoe-vygoranieprepodavateley-meditsinskogo-vuza-problema-i-puti-eeresheniya [in Russian].

10. Patirai, K. \& Richa, M. (2009). Effect of Job Stress and Personal Life Stress on Mental Health and Job Out-

\section{ЛІТЕРАТУРА}

1. Abbas S.G. The impact of work overload and coping mechanisms on different dimensions of stress among university teachers / S.G. Abbas, A. Roger // GRHю - 2013. - № 3 (8). - C. 93-118.

2. Балакірєва К. О. Профілактика та подолання професійного та емоційного вигорання : метод. рекоменд. / К. О. Балакірєва. - Київ, 2015. - 45 с.

3. Бойко В. В. Энергия эмоций : 2-е изд., доп. и перераб. / В. В. Бойко. -СПб.: Питер, 2004. - 474 с.

4. Mindfulness for teachers: a pilot study to assess effects on stress, burnout, and teaching efficacy / L. Flook, S.B. Goldberg, L. Pinger // Mind, Brain, and Education. - 2013. - Vol. 7 (3). - P. 182-195.

5. Гагалан Ю. Ресурси для подолання стресу. Стреси у професійній діяльності вчителя / Ю. Галаган // Психолог. - 2012. - № 4. - С. 29-31.

6. Holloway F. Support systems. 1. Introduction / F. Holloway, G. Szmukler, J. Carson [et al.] // Advances in Psychiatric Treatment. - 2000. - Vol. 6. - P. 226-235.

7. Jepson E. Individual contributory factors in teacher stress: The role of achievement striving and occupational commitment / E. Jepson, S. Forrest // British Journal of Educational Psychology. - 2006. - Vol. 76 (1). comes of Medical Professionals, Retrieved from http://papers.ssrn.com/sol3/papers.cfm?abstract_id=1437409

11. Schaufeli, W. B., Leiter, M. P., \& Maslach, K. (2009). Burnout: 35 years of research and practice. Career Development International, 14 (3), 204-220. doi: 10.1108/13620430910966406.

12. Zaichykova, T. V. (2005). Sotsialnopsykholohichni determinanty syndromu "profesiinoho vyhorannia" u vchyteliv [Socio-psychological determinants of burnout syndrome in teachers]. Extended abstract of candidate's thesis. Kyiv, Ukraine. Retrieved from: http://disser.com.ua/contents/8856.html

- P. 183-197.

8. Колоскова О. К. Особливості розвитку та проявів синдрому емоційного вигорання в лікарівпедіатрів / О. К. Колоскова, М. І. Поліщук, Т. М. Воротняк // Здоровье ребенка. - №7 (42). - 2012. - С. 1923.

9. Эмоциональное выгорание преподавателей медицинского вуза: проблема и пути ее решения / М. А. Лисняк, Н. А. Горбач, И. О. Логинова [и др.] // Сибирское медицинское обозрение. -2014. - № 6 (90). - C. 101-105.

10. Patiraj K. Effect of job stress and personal life stress on mental health and job outcomes of medical professionals [Електронний ресурс] / K. Patiraj, M. Richa // SSRN. 2009. - Режим доступу: https://papers.ssrn.com/sol3/papers.cfm?abstract_id=1437409

11. Burnout: 35 years of research and practice / W. B. Schaufeli, M. P. Leiter, K. Maslach // Career Development International. - 2009. - № 14 (3). - C. 204-220.

12. Зайчикова Т. В. Соціально-психологічні детермінанти синдрому «професійного вигорання» у вчителів : дис... канд. психол. наук: 19.00 .05 / Т. В. Зайчикова. - К., 2005. - 25 с.

Мар’яна Вікторівна Дікал,
кандидат медичних наук, доцент кафедри біоорганічної і біологічної хімії та клінічної біохімї̈,

Оксана Григорівна Чернюх, кандидат медичних наук, доцент кафедри біоорганічної і біологічної хімї та клінічної біохімії, Тетяна Михайлівна Білоус, кандидат медичних наук, доцент кафедри педіатрії та дитячих інфекиійних хвороб,

Ніна Іванівна Войткевич, стариий викладач кафедри іноземних мов, Вищчий державний навчальний заклад Украйни «Буковинський державний медичний університет», Театральна площча, 2, м. Чернівцуі, Україна

\section{ОСОБЛИВОСТІ ФОРМУВАННЯ ТА ПРОЯВИ СИНДРОМУ ЕМОЦЙНОГО ВИГОРАННЯ У ВИКЛАДАЧІВ ВИЩИХ НАВЧАЛЬНИХ МЕДИЧНИХ ЗАКЛАДІВ}

Стаття присвячена вивченню особливостей розвитку та проявів синдрому емоційного вигорання у викладачів теоретичних кафедр вищого навчального медичного закладу України «Буковинський державний медичний університет». Для діагностики рівня емоційного вигорання було використано адаптовану методику В. В. Бойко, за якою можна визначити не тільки симптоми емоційного вигорання, рівень сформованості та фази його розвитку, а й виявити наявність психосоматичних і психовегетативних порушень. Відмічено, що формування синдрому емоційного вигорання педагогів проходить у три фази: у фазі напруження він характеризується 
переважно надмірним переживанням психотравмуючих обставин, тривогою та депресією, у фазі резистенції проявляється економією емоційної сфери та емоційно-моральною дезорієнтацією, у фазі виснаження - емоційним дефіцитом, психосоматичними і психовегетативними порушеннями. Встановлено, що у 2 викладачів 3 27 сформувалися дві фази емоційного вигорання - напруження та резистенції, основними симптомами яких $\epsilon$ відчуття загнаності у клітку, що вказує на розвиток стану інтелектуально-емоційного затору та бажання швидшого завершення робочого дня, відчуття тривоги та депресії з паралельно сформованим симптомом редукції професійних обов'язків. Фаза резистенції була сформована у шести викладачів, домінуючими симптомами якої була редукція професійних обов'язків, що проявлялось зниженням інтересу до роботи та погіршенням професійної діяльності. Фази резистенції та виснаження сформувалася у чотирьох викладачів, найбільш вираженими симптомами яких були розширення сфери економії емоцій, що вказує на обмежене спілкування з аудиторією, зниження зацікавленості до роботи та емоційним дефіцитом, за якого люди втрачають професійні здібності із заміною позитивних емоцій негативними, стають грубими у спілкуванні. Виявлено, що у чотирьох викладачів переважно жіночої статі сформувалися всі три фази синдрому емоційного вигорання, для яких домінуючими були симптом переживання психотравмуючих обставин, що характеризується посиленням роздратування й недовіри до людей, накопиченням невдоволення ситуацією. Водночас найбільш вираженим є симптом розширення сфери економії емоцій, що вказує на небажання спілкування з аудиторією та зниження інтересу до роботи. Доведено, що у викладачів не виявлено особливостей проявів синдрому емоційного вигорання залежно від навчальної дисципліни, яку вони викладають, однак емоційне вигорання частіше розвивається при роботі зі студентами, у яких викладання предмету здійснюється англійською мовою.

Ключові слова: синдром емоційного вигорання, викладач, фаза напруження, фаза резистенції, фаза виснаження.

Reviewed by Doctor of Psychology, prof. A. Borysiuk 